\author{
Katarzyna Cieślak*, Jacek Hendel**, Szymon Kuczyński**
}

\title{
AN OVERVIEW OF COAL BED METHANE POTENTIAL IN POLISH COAL BASINS***
}

\section{INTRODUCTION}

History of hard coal mining in Upper Silesia, started in the mid-seventeenth century, which is confirmed in documents from 1657. On its site operated the open-pit mine in Murcki, where the first coal mine shaft was built and underground coal mining started in 1755 . Nowadays, after consolidation with KWK Staszic in 2010, and since then hard coal mine has operated as Murcki-Staszic, in the Katowice Coal Holding SA structure [1].

First coal mine in Lesser Poland District was established in 1767 in Szczakowa - nowadays in Jaworzno district [2]. Despite of long time experience in the Polish mining industry, methane associated with coal seams (CMM-coal-mine methane) was considered as a serious problem in coal exploration [3]. During the hard coal mine operation, methane together with wasted air was removed directly to the atmosphere through ventilation system, causing an increase in greenhouse gases (GHG) [4]. European Union adopted policy to reduce greenhouse gas emissions. Implementation of this policy causes an additional costs for mining company (related to methane emission). Ventilation methane content and methane drainage is shown in Figure 1.

Based on experience of USA, China and Australia, also in Poland, started to looking for the possibility to extract methane from coal beds. Due to US investors interest to perform assessment of methane extraction possibility from Polish coal basins, the first pilot projects has been performed in the early 90 s of twentieth century. Performed research were mostly based on a review of collected geological information and laboratory tests on samples taken from geological exploration drilling in the Upper Silesian Coal Basin.

* AGH University of Science and Technology, Student Scientific Association GEOWIERT, Krakow, Poland

** AGH University of Science and Technology, Faculty of Drilling, Oil and Gas Faculty, Department of Natural Gas Engineering, Krakow, Poland

*** This work has been performed within a Statutory Research realized at the AGH University of Science and Technology, Faculty of Drilling, Oil and Gas, Department of Natural Gas Engineering (11.11.190.555) 


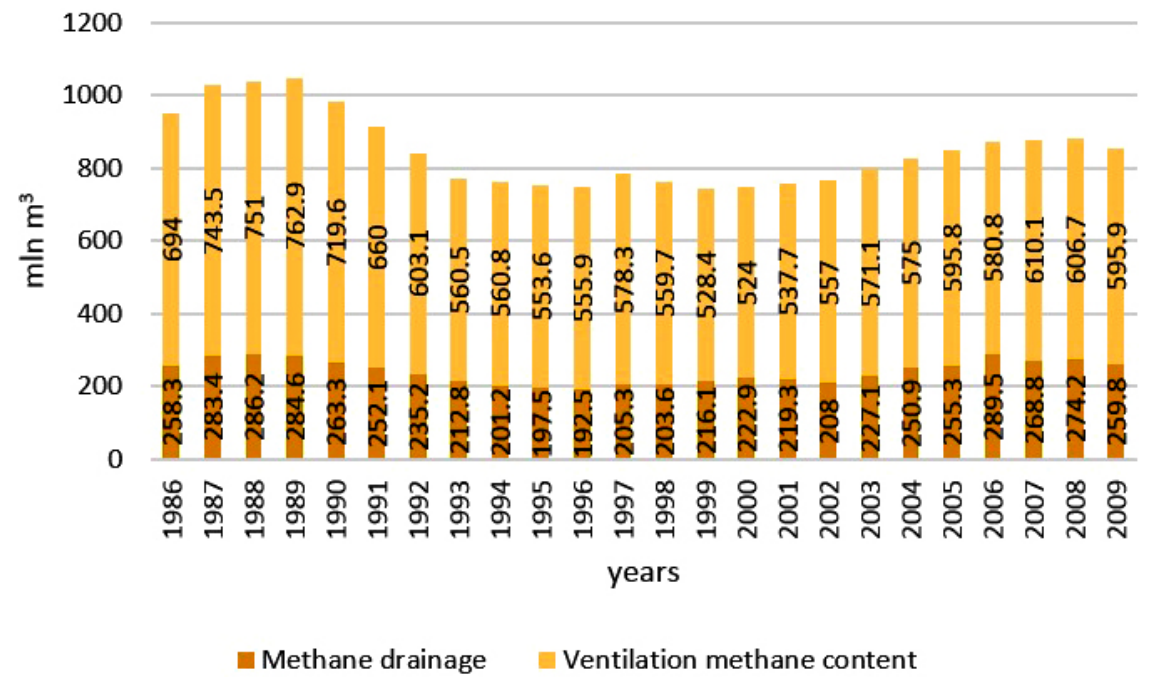

Fig. 1. Methane drainage (red bar) and ventilation air methane (yellow bar) between 1986 and 2009 [5]

Result of this research was decision to start two projects which will determine:

- the CBM production potential (Texaco),

- technical-economic conditions and parameters for Enhanced Coal bed Methane Recovery (E-CBM) with $\mathrm{CO}_{2}$ storage in hard coal seams (RECOPOL).

\section{COAL BED METHANE RESOURCES IN POLAND}

Coal bed methane resources in Poland are located in three hard coal basins:

1) the Lower Silesian Coal Basin (LSCB),

2) the Upper Silesian Coal Basin (USCB),

3) the Lublin Coal Basin (LCB).

Distribution of particular hard coal basins in Poland is presented in Figure 2.

\subsection{Lower Silesian Coal Basin (LSCB)}

Lower Silesian Coal Basin is located in Lower Silesia voivodeship, in the Sudety Mountains, and partially at the territory of Czech Republic. Basin covers an area of $600 \mathrm{~km}^{2}$ [7]. Geological resources of hard coal deposits in LSCB at the end of 2012 were estimated on $359.72 \mathrm{mln}$ tonnes. Exploitation of hard coal in the Lower Silesian Coal Basin was finished in 2000, when extraction in Nowa Ruda coal mine has been permanently discontinued. The reason for discontinuing exploitation from LSCB was difficult geological and mining conditions, which were causing extraction unprofitable [8]. Currently, at the LSCB area the drilling and geological works are performed by i.a. Coal Holding Ltd. which is a part of Balamara Resources Limited capital group. 


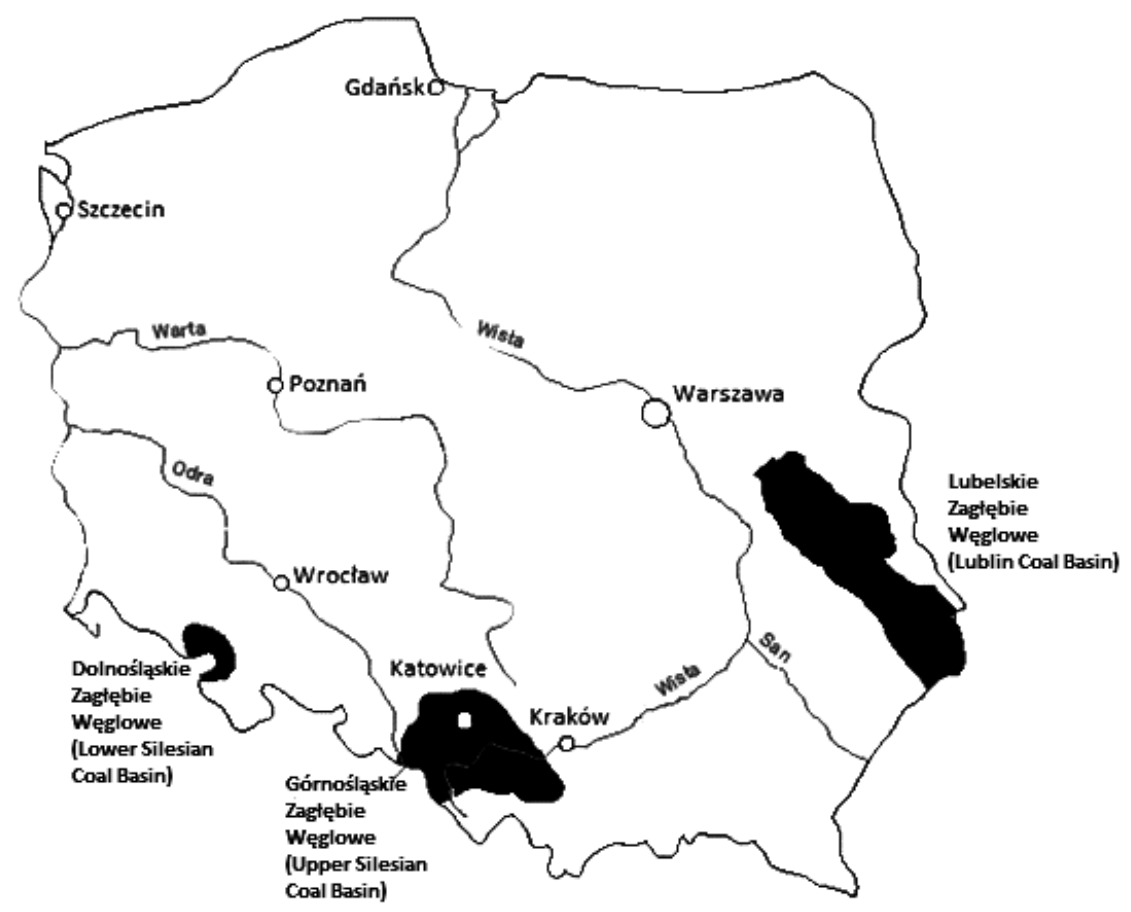

Fig. 2. Location of coal basins in Poland [6]

The aim of this work is better identification of geological and petrophysical parameters of hard coal deposits:

- Nowa Ruda Pole Piast Region Lech,

- Nowa Ruda Pole Piast Region Wacław.

It is planned to open for this deposits coking coal mine in 5-6 years [9].

Gas occurrence in LSCB have been identified in mines area up to a depth of hard coal exploitation, which is up to $1,000 \mathrm{~m}$. Rare boreholes made in areas directly adjacent to the documented hard coal deposits, extend gas content identification up to 1,500 $\mathrm{m}$ (rarely up to 2,000 m) [10]. Gas content ranges from 12.5-27.5 $\mathrm{m}^{3} /$ tonnes d.a.f. [11]. At the end of 2009, geological resources perspectives of coal bed methane in the Lower Silesian Coal Basin were estimated to $1.75 \mathrm{bln}^{3}$ [12]. Much bigger and more perspective is the Upper Silesian Coal Basin.

\subsection{Upper Silesian Coal Basin (USCB)}

Upper Silesian Coal Basin is located in southern Poland (Fig. 3). It has the shape of a triangular basin which is filled with significant thickness of Upper Carboniferous coal-bearing formations. USCB western boundary runs from the south-west to north-east (from Nový Jičin to Tarnowskie Góry). East boundary runs from northwest to southeast (from Tarnowskie Góry towards Myślenice), whereas southern boundary is contractually determine by Carpathian overthrust [13]. 


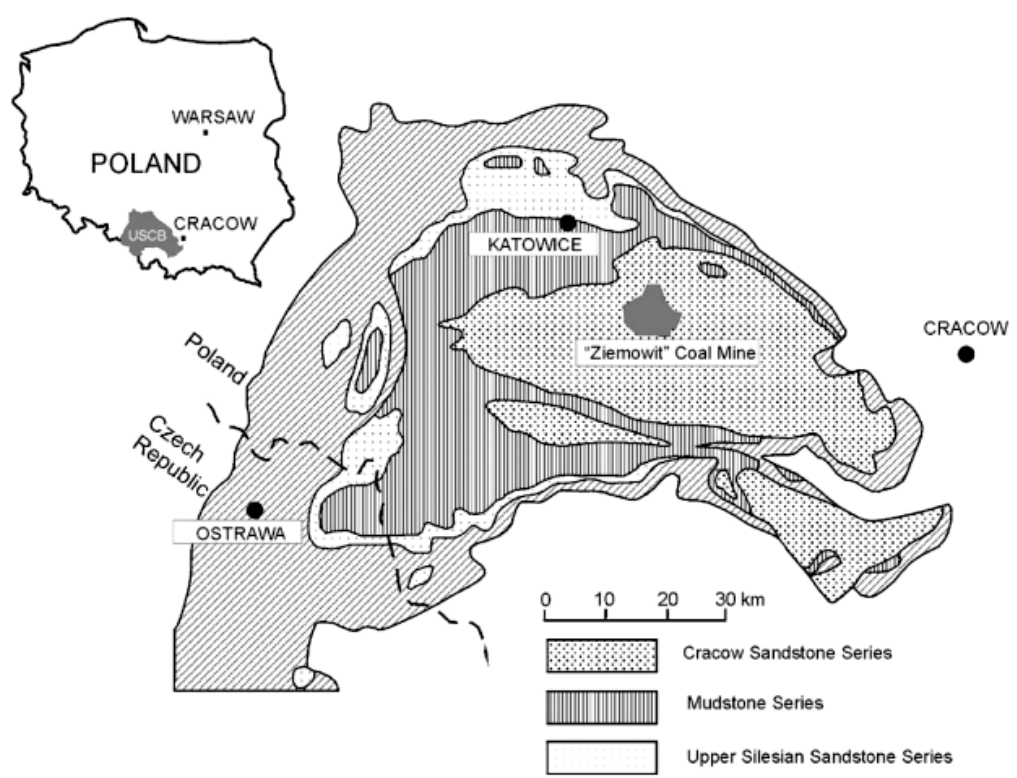

Fig. 3. USCB location in Poland [14]

At the Upper Silesian Coal Basin, by the end of 2012, there was 128 identified and documented hard coal deposits, including 50 fields which are exploited by 28 mines [13], 36 fields discontinued its operations. The remaining 42 fields are undeveloped. Documented hard coal resources in Poland are estimated to 48,226 mln tonnes, of which $80.1 \%$ is in the Upper Silesian Coal Basin. In Figures 4-6 worldwide, European and Polish perspective hard coal reserves were presented. Almost $75 \%$ of these reserves it is thermal coals, $25 \%$ is coking coals, and other types of coals are less than $2 \%$ of the total coal resources [8] (Fig. 7).

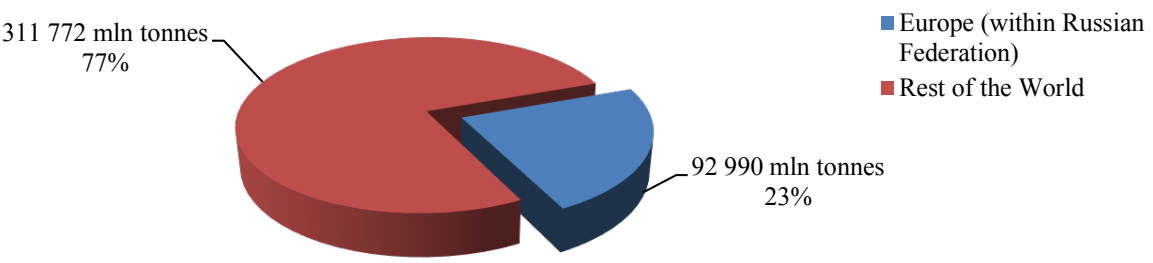

Fig. 4. Hard coal worldwide reserves [mln tonnes] [15]

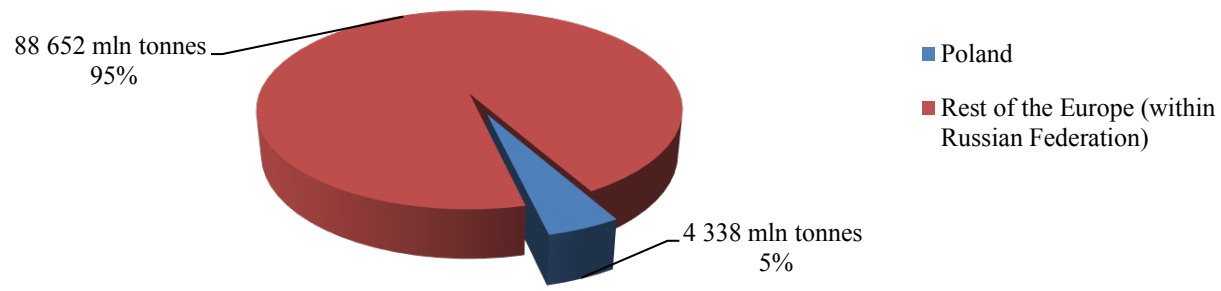

Fig. 5. European hard coal reserves [mln tonnes] [15] 


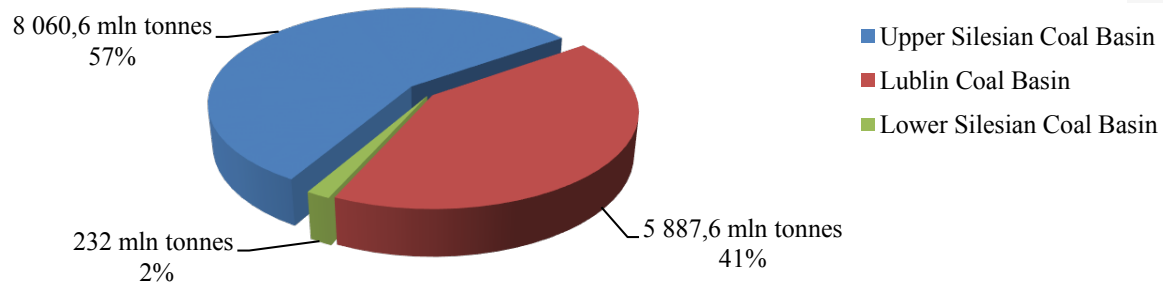

Fig. 6. Hard coal perspective resources of hard coal in Polish coal basins [mln tonnes] [8]

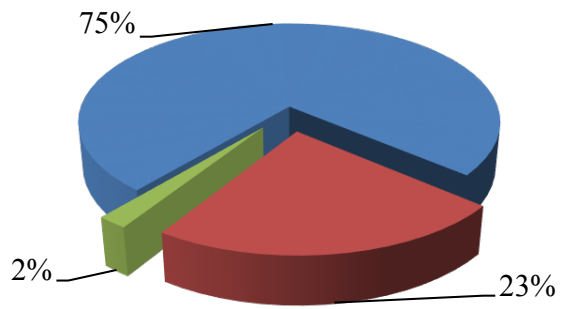

$$
\begin{aligned}
& \text { thermal coals } \\
& \text { coking coals } \\
& \text { w other types of coal }
\end{aligned}
$$

Fig. 7. Types of hard coal in Poland [8]

The Polish coal basins resources were summarized and showed in Table 1.

Table 1

Polish coal basins resources $[7,8,12]$

\begin{tabular}{|l|c|c|c|}
\cline { 2 - 4 } \multicolumn{1}{c|}{} & $\begin{array}{c}\text { Upper Silesian } \\
\text { Coal Basin }\end{array}$ & Lublin Coal Basin & $\begin{array}{c}\text { Lower Silesian } \\
\text { Coal Basin }\end{array}$ \\
\hline Area $\left[\mathrm{km}^{2}\right]$ & 5,600 & 9,100 & 600 \\
\hline Prognostic resources [mln t] & $9,193.4$ & $10,847.7$ & 0.39 \\
\hline Perspective resources [mln t] & $8,060.6$ & $5,887.6$ & 232 \\
\hline Number of hard coal deposits: & 128 & 11 & 7 \\
- Developed deposits & 50 & 1 & - \\
- Undeveloped deposits & 42 & 10 & 7 \\
\hline- Abandoned deposits & 36 & - & - \\
\hline Number of operating mines & 28 & 1 & 1.75 \\
\hline $\begin{array}{l}\text { Prognostic and perspective geological } \\
\text { resources of CBM [bln m }{ }^{3} \text { ] }\end{array}$ & 107 & 15 & - \\
\hline
\end{tabular}

Structure and operation of the hard coal mining sector in Poland is based on coal companies. Three of them belong to the State Treasury where the Ministry of Economy holds corporate governance. It can be seen increased interest in USCB deposits among private investors, both Polish and foreign, who are interested in areas such as: Studzionka-Mizerów, Orzesze, Niwka-Modrzejów, Polanka (near Oświęcim) and others. 
It can be mentioned that in September 2013, actions taken be the Śląski Węgiel company, which belongs to the Kulczyk Investments capital group, resulted in obtaining concession for exploration and recognition of hard coal and methane deposits in Orzesze [16].

Geological prognostic and prospective coal bed methane in the Upper Silesian Coal Basin are estimated to $107 \mathrm{bln}^{3}$ at the end of 2009 [12].

CBM in the Upper Silesian Coal Basin has been exploited since 1951. Between 1951-2005 total amount of methane production reached $10 \mathrm{bln} \mathrm{m}^{3}$. Approximately $270 \mathrm{mln}$ $\mathrm{m}^{3}$ of methane are produced annually. Almost all the methane comes from mines degasification $[11,17]$.

Documented resources of coal bed methane occur in 51 deposits in Upper Silesian Coal Basin. At the end of 2012 the recoverable resources included in The balance of mineral... [8] are estimated to $87.6 \mathrm{bln}^{3}$, including:

- in the areas of exploited coal deposits $-39.3 \mathrm{bln}^{3}$ in 30 fields,

- outside the coal mining -16.1 bln $^{3}$ in 13 fields,

- methane is present as a main fossil - 32.2 bln $\mathrm{m}^{3}$ within 8 fields [8].

In 90s, American companies, such as Amoco, Texaco, Metanel and other, performed assessment of coal bed methane extraction possibility in the Upper Silesian Coal Basin [18]. A few years later, Texaco Silesia Ltd. performed pilot project to determine the production potential of CBM [19]. Exploitation was carried out by the multilateral completion and hydraulic fracturing of several gas-bearing seams [20]. In short term, after the moment when methane had occurred into the wellbore, there was a sharp drop in gas production, caused by a rapid loss of conductivity in fractured layer around the wellbore (Fig. 8). It might be caused by perforation choking by backflow fluid or coal dust, permeability and conductivity changes due to influence of stress changes in strata or other unknown factors [19].

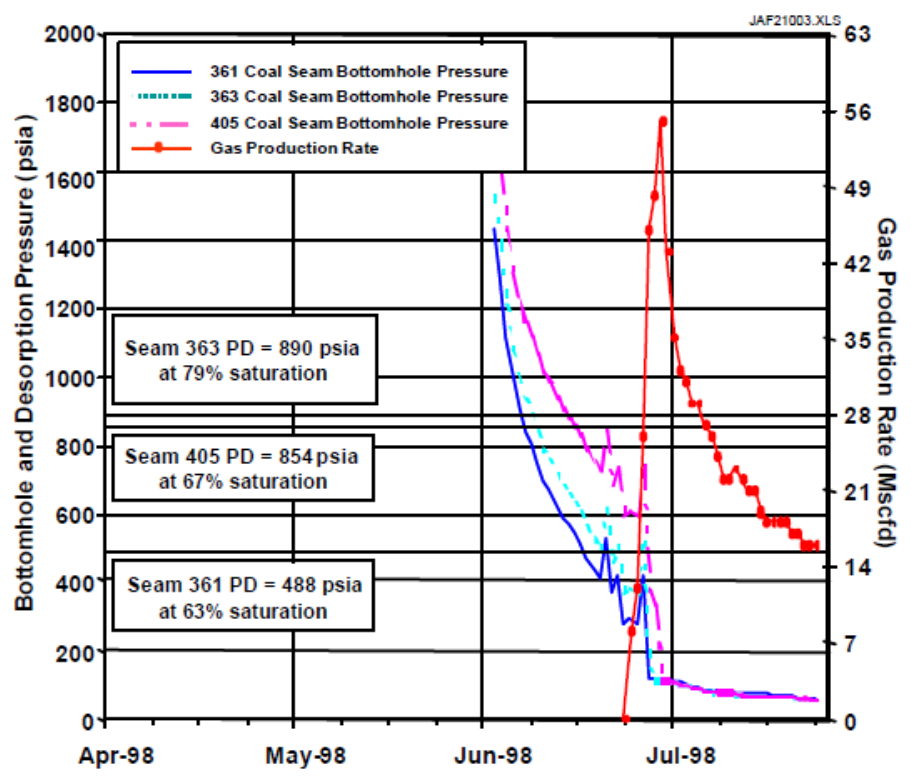

Fig. 8. Gas production (right), bottom and desorption pressure (left), CBM Texaco project [19] 
To determine technical-economic conditions of $\mathrm{CO}_{2}$ storage in coal seams, research-industrial consortium was created. To reach this aim the first European $\mathrm{CO}_{2}$-ECBM project called RECOPOL was performed between 2001 and 2006 in area of USCB [21]. Because of complications which occurred during completion and almost no methane flow into the wellbore, conclusion of RECOPOL project was not optimistic. According to van Wageningen and Maas [21], the adsorption of carbon dioxide and methane desorption on coal are extremely slow. Moreover, coal seams have low thickness and permeability (in extreme cases up to $1 \mu \mathrm{D}$ ), and coal contains a lot of ash.

Recently, the Polish Geological Institute - National Research Institute (PGI-NRI) started the R\&D projects which aim is to determine and check opportunities of methane drainage from coal seams in near area of working hard coal mine. PGI-NRI drilled directional horizontal wellbore to perform degasification of coal layers before its exploration.

\subsection{Lublin Coal Basin (LCB)}

Basin is located between Wieprz River and Bug River. The Lublin Coal field is important for industry, due to occurrence of hard coal [7]. LCB exploration and particularly the knowledge state of its borders is relatively weak. Defined perspective deposits are assumed to approximately $9,100 \mathrm{~km}^{2}$. Documented deposits cover an area of approximately $1,000 \mathrm{~km}^{2}$. In the Lublin Coal Basin operates the newest and most efficient coal mine in Poland - Lubelski Węgiel Bogdanka SA.

Bogdanka hard coal mine has been located in the Central Coal District which is located in south-eastern - best explored - part of LCB. The Central Coal District is located within the boundaries of Lublin Polesie and only its small part is located on the Lublin Upland [22]. Hard coal resources in LCB represent approximately 19.2\% of Polish coal resource included in The balance of mineral... [8].

Similar to USCB and LSCB, the Lublin Coal Basin also seems interesting for private investors. In Lublin region Australians want to build new mines. Also, Kopex SA is interested in building new mine, which low cost of hard coal production will become a serious competitor to the Lubelski Węgiel Bogdanka [16, 23].

At the moment, due to poor identification of the LCB deposits, it is difficult to assess the economic importance of coal-bed methane resources in this basin. At the end of 2012, CBM perspective resources was estimated to $15 \mathrm{bln}^{3}$ [12].

\section{CONCLUSIONS}

Coal bed methane in Poland occurs within three coal basins of which the best recognized and most promising is the Upper Silesian Coal Basin. Approximately $80.1 \%$ of proved balance of coal deposits resources in Poland occurs in the Upper Silesian Coal Basin, where 50 fields are operated by 28 mines. Thus, since early $90 \mathrm{~s}$ of the $20^{\text {th }}$ century the USCB is attractive for foreign companies which perform evaluation of coal bed methane obtaining possibility as main fossil. However, all previous attempts to commercial 
production of CBM did not bring expected results, but they constitute extensive information database for current and future research towards CBM exploitation. Prognostic resources of coal bed methane in USCB are estimated to $107 \mathrm{bln}^{3}$. Recoverable balance resources are estimated to $87.6 \mathrm{bln}^{3}$. Much smaller perspectives are related to the poorly identified regions of Lublin Coal Basin and Lower Silesian Coal Basin. It is estimated that balance resources of hard coal in LCB, represents approximately $19.2 \%$ of Polish hard coal balance resources. In LCB region, operates only one mine, which is the newest and most efficient hard coal mine in Poland.

Coal bed methane perspective resources in Lublin Coal Basin are estimated at $15 \mathrm{bln} \mathrm{m}^{3}$, whereas for Lower Silesian Coal Basin, coal bed methane (CBM) perspective resources are estimated at $1.75 \mathrm{bln} \mathrm{m}^{3}$. Currently, there is no exploitation of hard coal in the Lower Silesian Coal Basin region. Structure and operation of the hard coal mining sector in Poland is based on coal companies. Three of this coal companies belong to the State Treasury. It can be seen increased interest in Polish deposits among private investors, whose projects aim to improve deposit identification rate for Polish coal basins as well as new mines construction.

\section{REFERENCES}

[1] KWK Murcki-Staszic, [on-line:] www.kwkstaszic.pl [access: November 2013].

[2] Leś-Runicka M.: Szczakowa-pierwsza w Polsce kopalnia węgla kamiennego. KWK sp. z o.o., Jaworzno 2011.

[3] Karacan C.Ö., Esterhuizen G.S., Schatzel S.J., Diamond W.P.: Reservoir simulation-based modeling for characterizing longwall methane emissions and gob gas venthole production. International Journal of Coal Geology, vol. 71, 2007, pp. 225-245.

[4] Kaliski M., Szurlej A., Wojciechowski R.: Zagospodarowanie metanu z pokładów węgla - stan obecny i perspektywy. Polityka Energetyczna, t. 16, z. 4, 2013, pp. 189-200.

[5] Nawrat S., Napieraj S.: Proekologiczne wykorzystanie metanu z kopalń węgla. Kraków 2010, [on-line:] www.ptumk.umcs.lublin.pl.

[6] EURACOAL, [on-line:] www.euracoal.org [access: November 2013].

[7] Gonet A., Nagy S., Rybicki C., Siemek J., Stryczek S., Wiśniowski R.: Technologia wydobycia metanu z pokładów węgla (CBM). Górnictwo i Geologia, t. 5, z. 3, 2010, pp. 5-25.

[8] Szuflicki K., Malon A., Tymiński M (red.): Bilans zasobów złóż kopalin w Polsce wg stanu na 31 XII 2013 r. [The balance of mineral resources deposits in Poland as of December 31, 2012]. Państwowy Instytut Geologiczny - Państwowy Instytut Badawczy, Warszawa 2013, [on-line:] www.geoportal.pgi.gov.pl/surowce [access: November 2013].

[9] Dudała J.: Projekt Nowa Ruda - wegiel koksujacy: pierwsze odwierty wykonane. [on-line:] www.wnp.pl [access: November 2013].

[10] Łabaszewski W.: Potencjat metanonośności pokładów węgla w rejonie Dolnoślaskiego Zagłębia Węglowego w aspekcie możliwości prowadzenia prac poszukiwawczo-rozpoznawczych. [on-line:] www.mos.gov.pl [access: November 2013]. 
[11] Kędzior S.: Potencjat zasobowy metanu pokładów węgla $w$ Polsce $w$ kontekście uwarunkowań geologicznych. Gospodarka Surowcami Mineralnymi, t. 24, z. 4/4, pp. 155-173.

[12] Kwarciński J.: Metan pokładów węgla. [in:] Wołkowicz S., Smakowski T., Speczik S. (red.), Bilans perspektywicznych zasobów kopalin Polski wg stanu na 31 XII 2009, Państwowy Instytut Geologiczny - Państwowy Instytut Badawczy, Warszawa 2011, pp. 63-70.

[13] Wilczyński M.: Zmierzch węgla kamiennego w Polsce. Fundacja Instytut na rzecz Ekorozwoju, Warszawa 2013.

[14] Misiak J.: Petrography and depositional environment of the No. 308 coal seam (Upper Silesian Coal Basin, Poland) - a new approach to maceral quantification and facies analysis. International Journal of Coal Geology, vol. 68, 2006, pp. 117-126.

[15] BP Statistical Review of World Energy, 2013 [on-line:] www.bp.com [pdf].

[16] Dudała J.: Nowe kopalnie, czyli Australijczycy, Kulczyk i Kopex. [on-line:] www.wnp. pl [access: December 2013].

[17] Kędzior S., Hadro J., Kwarciński J., Nagy S., Młynarczyk M., Rostkowski R., Zalewska E.: Warunki naturalne występowania i metody eksploatacji metanu pokładów węgla $w$ wybranych zagłębiach węglowych USA oraz możliwości rozwoju eksploatacji tego gazu w Polsce - sprawozdanie z wyjazdu szkoleniowego do USA. Przegląd Geologiczny, t. 55, nr 7, 2007, pp. 565-570.

[18] Siemek J., Rychlicki S., Rybicki C.: Perspectives of methane recovery from coal beds in Poland. Proceedings of the $14^{\text {th }}$ World Petroleum Congress, vol. 3, John Wiley \& Sons, 1994, pp. 269-272.

[19] McCants C.Y., Spafford S., Stevens S.H.: Five-Spot Production Pilot on Tight Spacing: Rapid Evaluation of Coalbed Methane Block in the Upper Silesian Coal Basin, Poland. The 2001 International Coalbed Methane Symposium, University of Alabama, Tuscaloosa, May 2001, pp. 193-204.

[20] Kwarciński J., Hadro J.: Metan pokładów węgla na obszarze Górnoślaskiego Zagłębia Weglowego. Przegląd Geologiczny, vol. 56, nr 6, 2008, pp. 485-490.

[21] Wageningen W.F.C. van, Mass J.G.: Reservoir Simulation and Interpretation of the RECOPOL ECBM Pilot in Poland. 2007 Coalbed Methane International Symposium, Tuscaloosa, 0702, 2007.

[22] Lubelski Węgiel "Bogdanka", [on-line:] www.lw.com.pl [access: November 2013].

[23] Dudała J.: Zagraniczny kapitat szansa dla polskiego węgla. [on-line:] http://gornictwo. wnp.pl/zagraniczny-kapital-szansa-dla-polskiego-wegla,210862_1_0_0.html [access: November 2013]. 